\title{
体外衝撃波による腎・尿管結石破砝術の臨床経験
}

\begin{tabular}{rllll} 
& 丹 & \multicolumn{1}{c}{ 田 } & 均 \\
& 加 & 藤 & 修 & 爾 \\
東札幌三樹会病院 & 坂 & & 丈 & 敏 \\
& 大 & 西 & 茂 & 樹 \\
& 中 & 嶋 & 久 & 雄 \\
札幌医科大学泌尿器科学教室 & 熊 & 本 & 悦 & 明
\end{tabular}

\section{CLINICAL EXPERIENCES OF RENAL AND UPPER URETER STONES BY EXTRACORPOREAL SHOCK WAVE LITHOTRIPSY (ESWL)}

\author{
Hitoshi Tanda, Shuji Kato, Taketoshi Saka, Shigeki Ohnishi and Hisao Nakajima \\ Urological Clinic of Higashisapporo Sanjukai Hospital \\ Yoshiaki Kumamoto \\ Department of Urology, Sapporo Medical College
}

For the first time in Japan, we have treated renal and upper ureteral stones using ESWL since September 1st 1984. The results have been satisfactory. We present our experience with ESWL.

We have treated 101 cases of renal and upper ureteral stones in 107 treatments. In $90 \%$ of these patients epidural anasthesia was used. The ages of the cases ranged from 20 to 74 years old, including 30 cases of women and 71 cases of men. The size of the stones varied from less than $1 \mathrm{~cm}$ to staghorn calculi. To break up these stones, 400 to 2200 shock waves were necessary. In 80 cases $(79 \%)$ less than 1500 shock waves were used. The treatments lasted from 7 to 60 minutes with the average time from 11 to 40 minutes $(86 \%)$.

$76 \%$ of all cases had spontaneous sandy stone passage without complain. But $24 \%$ had such symptoms as fever and/or pain. 5 cases experienced dull pain or fever due to stone fragments that filled the lower ureter after distingrating large stones. Ureteral meatotomy in such cases produced satisfactory results. None of these patients needed open operation.

In $99 \%$ of the cases the size of the discharged stone fragments was less than $2 \mathrm{~mm}$. Although our observation of the patients was still short we found natural discharge of stone fragments after ESWL treatment in 47 cases. The other cases had only sandy stones that easily discharged. Analysis of the stones showed that $82 \%$ were composed of caoxalate. Besides caoxalate 2 cases were composed of urate, 1 case was composed of cystine.

From these present findings, it appears that ESWL can break all stones of any size, composition, and the number of stones. The important thing for the future is how to facilitate the discharge of stone fragments after ESWL treatment.

We are confident that ESWL will soon take the place of surgery in treating urinary tract calculi.

\footnotetext{
要旨：1984年 9 月 1 日より, 本邦で初めて, 上部尿路結石に対して, ESWL 施行し, 良好なる成績を上 げたので報告する。

上部尿路結石 101 例に対して，107回施行した。硬膜外麻酔を101例中96例 $(90 \%)$ に施行した。年齢は 20 74歳で, 男71例, 女30例である. 結石の大きさは鋳型結石 ( 5 例)から $1 \mathrm{~cm}$ 以下迄に及んだ. Shock wave の回数は400 2,200回で, 1,500回以下が80例（79\%）であった。治療時間は 7 分から60分間で, 通常は11 40分間で87例 (86\%) であった。治療後の副作用は76\%の症例には無かった。あっても発熱，
} 
疼痛（鈍痛が殆んどで疝痛は 1 例）であり，発熱は腎孟炎として治療した。尿培養にて 12 例に起炎菌を 同定し得た。破砕された結石が多量に尿管下端に充満（stone street）している症例で，発熱，鈍痛があ る場合に尿管口切開を 5 例に施行し良好であった。破砕した結石の大きさは $2 \mathrm{~mm}$ 以下が $99 \%$ な゙あった。 治療後, 自然排石症例は follow up 期間は短いが47例で, 残りの症例は排泄可能の砂状結石のみである. 結石成分は, 蓚酸カルシウムを中心とした成分が, $82.2 \%$ あっった。 その他尿酸 2 例, cystine 1 例であっ た.

ESWL は結石の大きさ，個数，成分にも拘らず，全て破砕された事が判明したが，向後破碀された結 石の排泄をどう処理するかが，問題になる．更に，上部尿路結石症の open surgery に代わる最大の中心 的役割を果たすと確信した。

\section{緒言}

西独の Dornier 社製腎結石破砕器を用いた，体外衝 撃波による腎・尿管結石に対する破砕術（Extracorporeal Shock Wave Lithotripsy 以下 ESWL と略記 す）は，1980年 2 月より Munich 大学泌尿器科教室に て臨木治験が世界ではじめて施行され，良好なる成績 を上げている。

今度, 本邦（東札幌三樹会病院 札幌市）に始めて 導入され, 1984年 9 月 1 日より臨床治験が行なわれた。 同年11月上旬まで，腎・尿管結石症例101症例（107回 施行）に対して治験し，良好な成績を上げたので，主 にその治療方法, 症例の供覧, 治療成績の中間報告を する。

\section{原理および器械装置}

ESWL の原理抢よび器械装置については, すでに文 献で詳細に報告されているので1) 3)，ここでは簡単に 紹介寸る．図 1 に，本邦で始めて設置された東札幌三 樹会病院の結石治療室の主な所を示した。図 1 に示し た如く, 治療室 (図 2 (1)参照), 操作室 (図 2 (2)参照),
器械室とに分れる。器械室の中には，脱気装置，軟水 化装置, 温水供給装置, $\mathrm{N}_{2} \mathrm{O}$ ガス供給装置, 油圧供給 装置等がある。

治療室の中には, 治療装置があり, それは, 油圧式 の患者懸架システム (図 3 参照), 温水槽（容量約 200 $l$ : 図 4 参照), 高電圧 $(10 \mathrm{KV} \sim 30 \mathrm{KV}$ : 図 4 に示した 温水槽の底部)を発生させる装置（spark generator）, $\mathrm{X}$ 線透視システム（図 4 に示した温水槽の左右側面に 位置する), 温水槽の中のほぼ中央の底部に位置する半 随円形の反射板（semiellipsoidal reflector）とその中 にある電極棒（shock wave applicator）とからなる.

操作室 (図 2 (2)参照) の中には, X 線透視 TV モニ ター 2 台とX線操作・結石の位置を移動し, 確認する 操作器 (control cabinet) とからなる.

ESWLの原理を簡単に略記すると, spark generator から spark が出され, その周囲の水が急激に温め られる時に, 膨張し, shock wave を発生, これを結石 に集中させる，そして何回か繰り出される shock waveにより, 結石が小結石に少しずつ破砕されるこ

図 1 東札幌三樹会病院の腎結石治療棟（1 部）の設計図 （竹中工務店北海道支店 設計者：田中 裕氏提供）

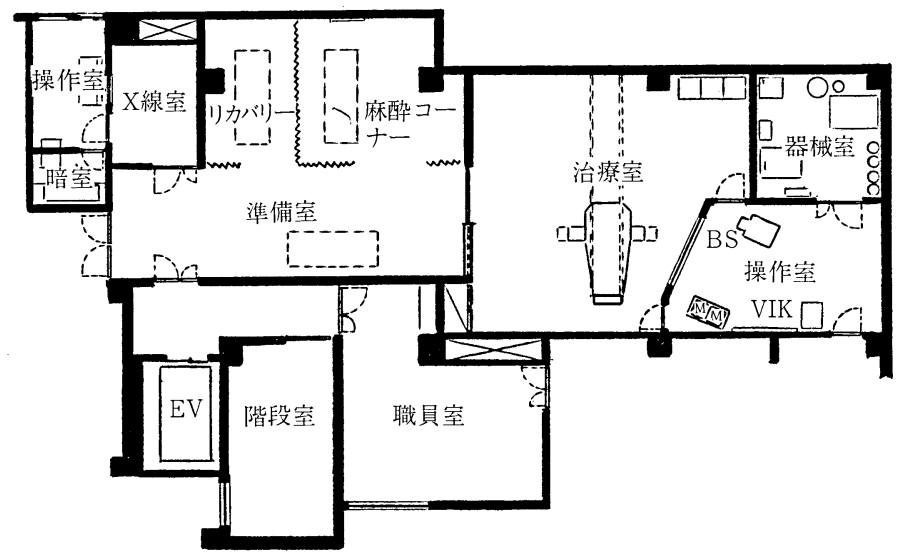


図 2 - (1)

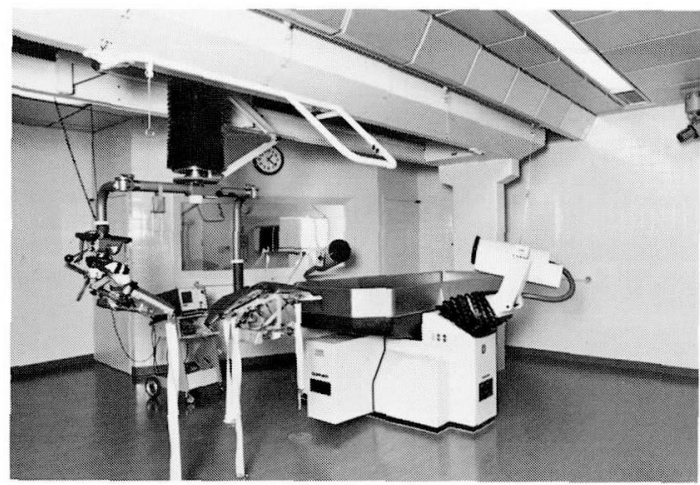

図 2 -(2)

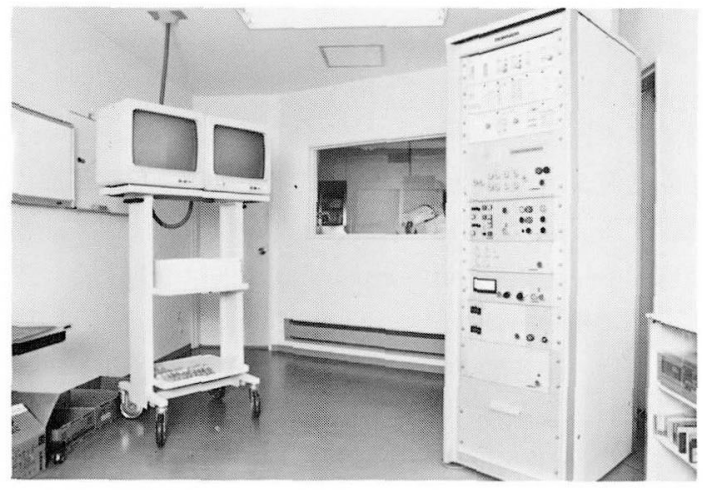

図 3 患者懸架システム

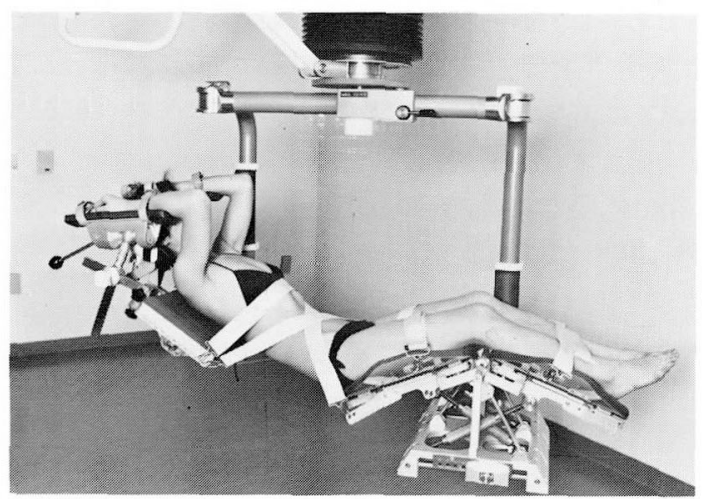

とになる。すなわち,

(1) $10 \sim 30 \mathrm{KV}$ (通常 $18 \mathrm{KV}$ ) の高電圧により electrolodeにて, 温水中にspark を発生させる。

(2) spark は周囲の温水 (液体) を急激な爆発的気化 を起こす，その時に shock wave を生ずる。これが円 孤状に搪がる。
図 4 治療器（温水槽，2対のエックス線装置等）

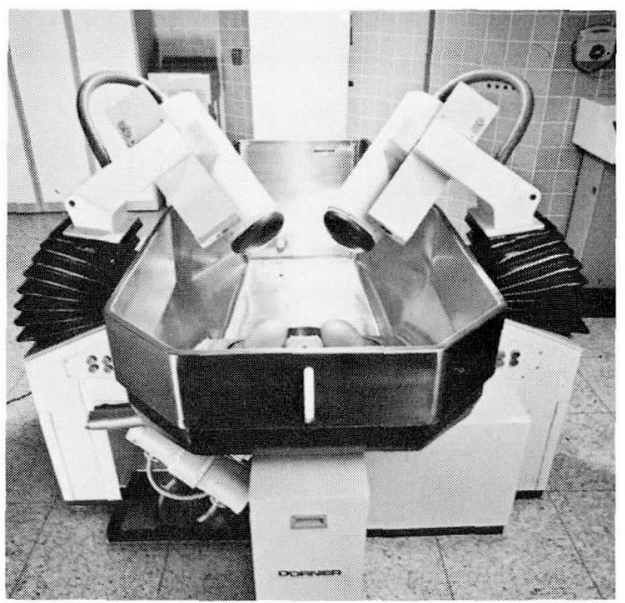

(3) Shock wave は円孤状に拡がるので，これを 1 点 に集中させる為には, shock waveを発生させた後，も う1点の焦点に集中させれば良い事になる。そこで, 棈円形は 2 つ焦点をもつので, semiellipsoidal reflectorが考案された。楕円形を半分に切った reflector は, shock waveを発生させるのを第 1 焦点 とし, 結石の位置を第 2 焦点にしている。この焦点は $1 \mathrm{~cm}^{2}$ の広さをもつという.

(4) Shock wave は, 音響学的伝導率(インピーダン ス）に差がなければそのまま伝播される。従って生体 の組織・臓器は水と同じ様な成分の為, shock wave は 水中から発生された後, 何ら生体に損傷を与えること なく伝播される．結石といら異物（固体）に当ると， shock waveの一部が反響し高压の振動が生じて, 結 石（固体）の破砕が起る. これを反復 shock waveを 与えることにより少しずつ破砕されてくる.

(5) Shock waveによって破砕された小結石の粒子 は,わずかな散乱運動(瞬間的に $2 \times 10^{-3}$ joule の運動工 ネルギー）を行う。その力は, 空から降る雨粒位の強 さである為, 腎・尿管の粘膜への損傷・影響は殆んど ないと云われている。

\section{ESWL の操作と治療の方法}

著者らの実際に行った治療方法について, 簡単に略 記する。

1. 腸内ガス発生防止の為に, 低線維食を治療前数日 間摂取させるのが理想であるが，通常，普通食をとら せた。

2. 通常の腰椎麻酔の前処置をした.

3. 麻酔は, 硬膜外麻酔を施行した。硬膜外にカテー 
テルを留置しないで，1.5\%キシロカインを $15 \mathrm{ml}$ 硬膜 外に注入した。麻酔後心電図のモニターを装備した。

4. 上記 2,3 の施行中に温水槽の中に $37 \sim 39^{\circ} \mathrm{C}$ の脱 気した温水を自動供給装置により入れておいた。

5. 図 3 の如く患者を固定した後, 油圧式りフトで温 水槽の中につけた。次いで, 操作室中の control cabinetにある位置確認用ボタンにより，結石の位置と semiellipsoidal reflector の位置に合うように微動操 作した.

6. 操作室にて，2軸のX線透視で, 結石の位置を確 定した(図 5 参照)。治療室でのX線の散乱線を測定し て，その完全性を確認してみたところ，図 6 (1)～(4)に 示した如く, 破碎器抢よび治療室附近では, 基準值以 下で問題にならない程度であった。

7. 治療開始する際に, shock wave の発生音に対し て，患者に不安を与学ない為に，1回発生させ，患者 に説明するようにした。この発生音は，予想した以上 に大きいので，実際に，音量測定してみた。その結果 を表 1 に示したが，治療室では，80〜100ホンであり， 病院内での発音防止の設計指標によると，かなりの騒 音となり,「無視でさない大声会話 $(3 \mathrm{~m}) 」$ 」音量であっ た.

8. 結石破砕は, shock wave を断続的に発射させて 行らものであるが, その回数は, 結石の大ささ, 位置, 結石成分により異った。

9. 治療時間は, shock wave の回数の他, 50〜100

図 5 結石を装置の固定焦点に合わせるのに使用しま す. 2 対のエックス線装置が取り付けられています。 温水槽底部にェックス線管が，上部の自在フレーム にイメージインテンシファイヤーが取り付けられて います。（株式会社パスコメディカルシステムズ提 供)

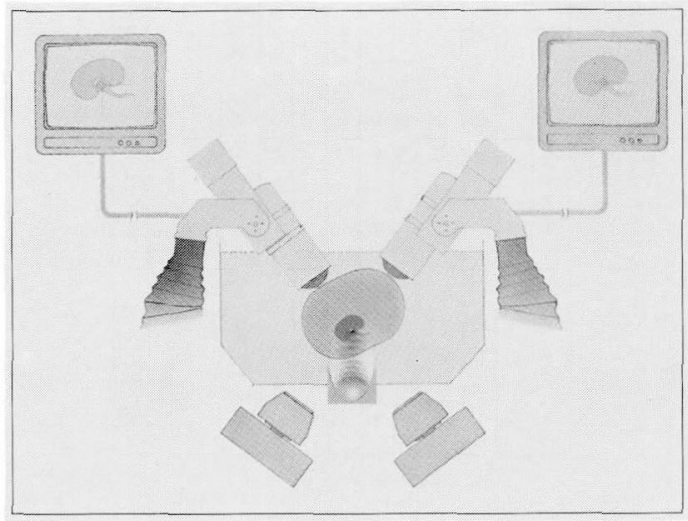

回毎に, X線透視で snap shoot で結石破砕状態と, 結 石の位置を確認するので，そのX線透視操作する時間 も影響した。

10. X線被曝時間は, 上記 8,9 上り多少異なるが, $5 \sim 60$ 秒間であった。

11. 治療は, 結石が破砕された結石陰影像を確認し て終った.

12. 治療直後, 腎, 膀胱部の単純撮影 (以下 KUB と 記す）で粉々になった事を確認した。

13. 治療室の中には, shock waveの音を消音させ る為に, 軽音楽を back ground music として流した。

14. 治療後，可及的に水分を摂取させた。 李た，尿 と一緒に排泄された砂状結石を集め, 結石分析に提出 した.

\section{(1) 麻酔}

全身麻酔は，浅い呼吸にて治療するといら意味では 有用であるが，我々は，簡易である硬膜外麻酔を多用 した(表 2 参照)。麻酔効果が不充分の時には, 静脈麻 酔を併用した。

（2）年齢と性

ESWL を施行した101例 (男71例，女30例)の年齢層 別男女数を表 3 に示した. 最少年齢は 20 歳の女子で, 最高年齢は74歳の男子であった。

(3) 結石の位置・個数・大きさ

表 4 に示した如く,鋳型結石 5 例を含む腎結石68例， 腎・尿管結石 6 例，尿管結石 27 例に施行した。当初は， 拇指頭大までの結石をESWLの適応と考光ていた が，表 4 に示したように，1～2 腎杯にわたる鋳型結 石 4 例，完全鋳型結石 5 例にも治療した。これらの多 量排泄を予想される結石群に対しては，2３回に分 けて治療した。1回目に治療した砂状の結石群が完全 消失した後に，2 回目の治療を試みた。また両側性の 場合は，片側ずつ試みた。

結石の数は表 4 に示したように， 1 個が67例， 2 個 以上が34例であった。 2 力所以上の症例には, 小結石 の部位により治療した。

結石の大きさは表 5 に示したが, $2 \mathrm{~cm}$ (長軸)以下が 101例中78例（77\%) であった。しかし， $3 \mathrm{~cm}$ 以上に及 ぶ大結石 9 例 $(9 \%)$ にも施行した。

次いで, 腎盂尿管移行部結石を含む尿管結石(腰部： $\mathrm{L}_{4}$ 以上の高さまでの尿管結石）23例（らち腎杯合併 7 例）に対して治療した。腎孟内結石に比し，成功率が 少ないので尿管バルーンを插入して水分を注入しなが 

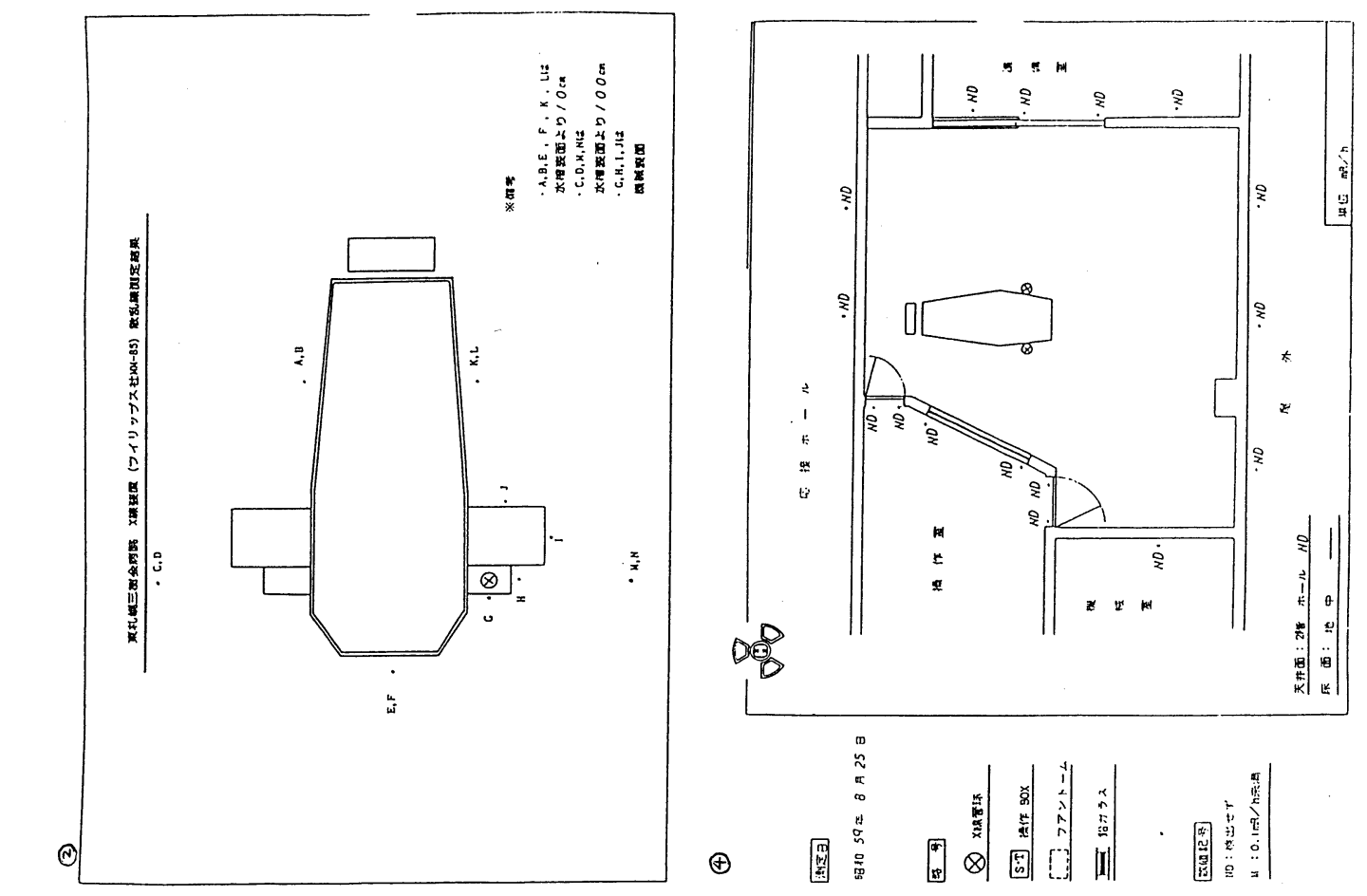

6
$\times$
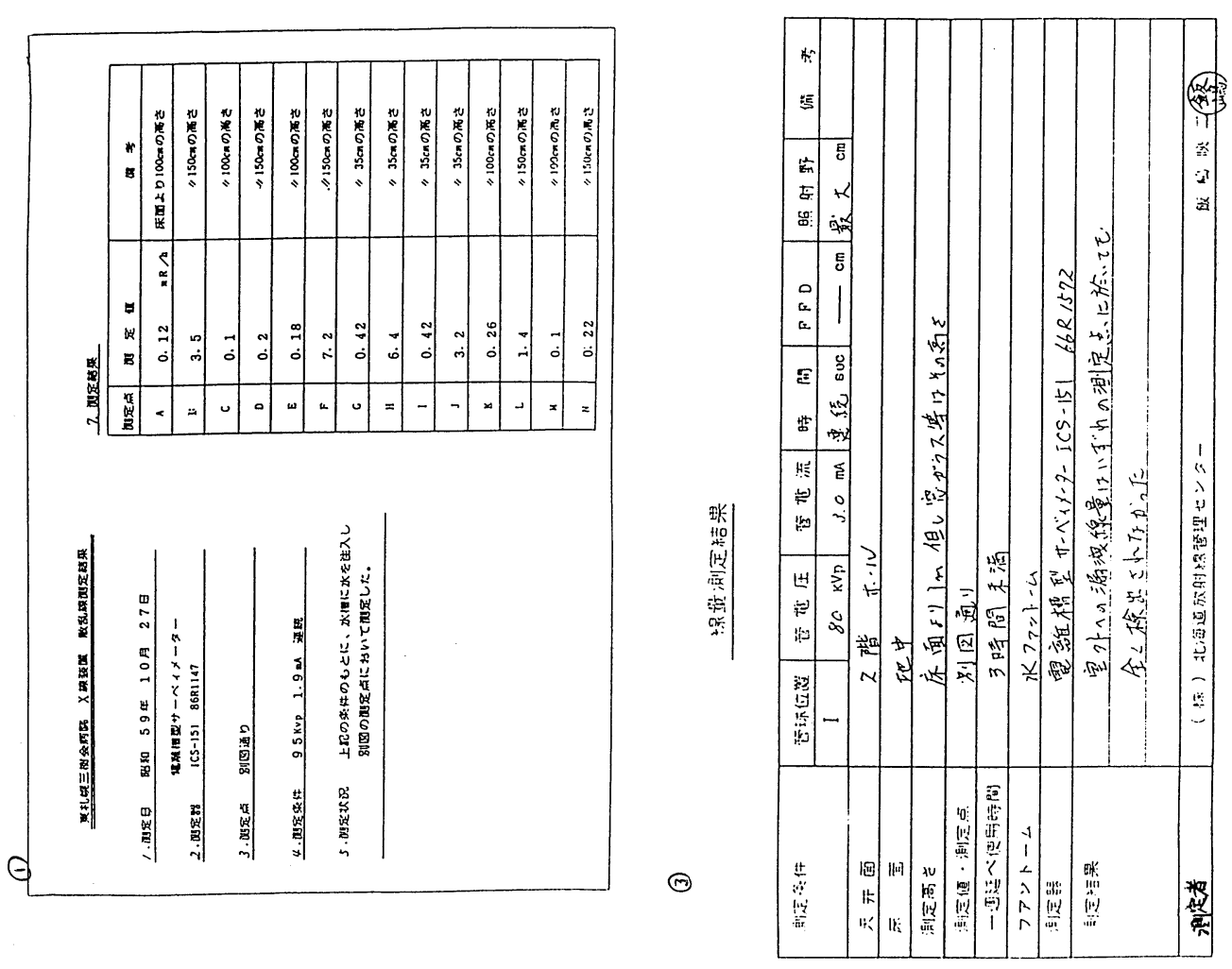
表 1 東札幌三樹会病院・腎臓結石破厒器の音量測定

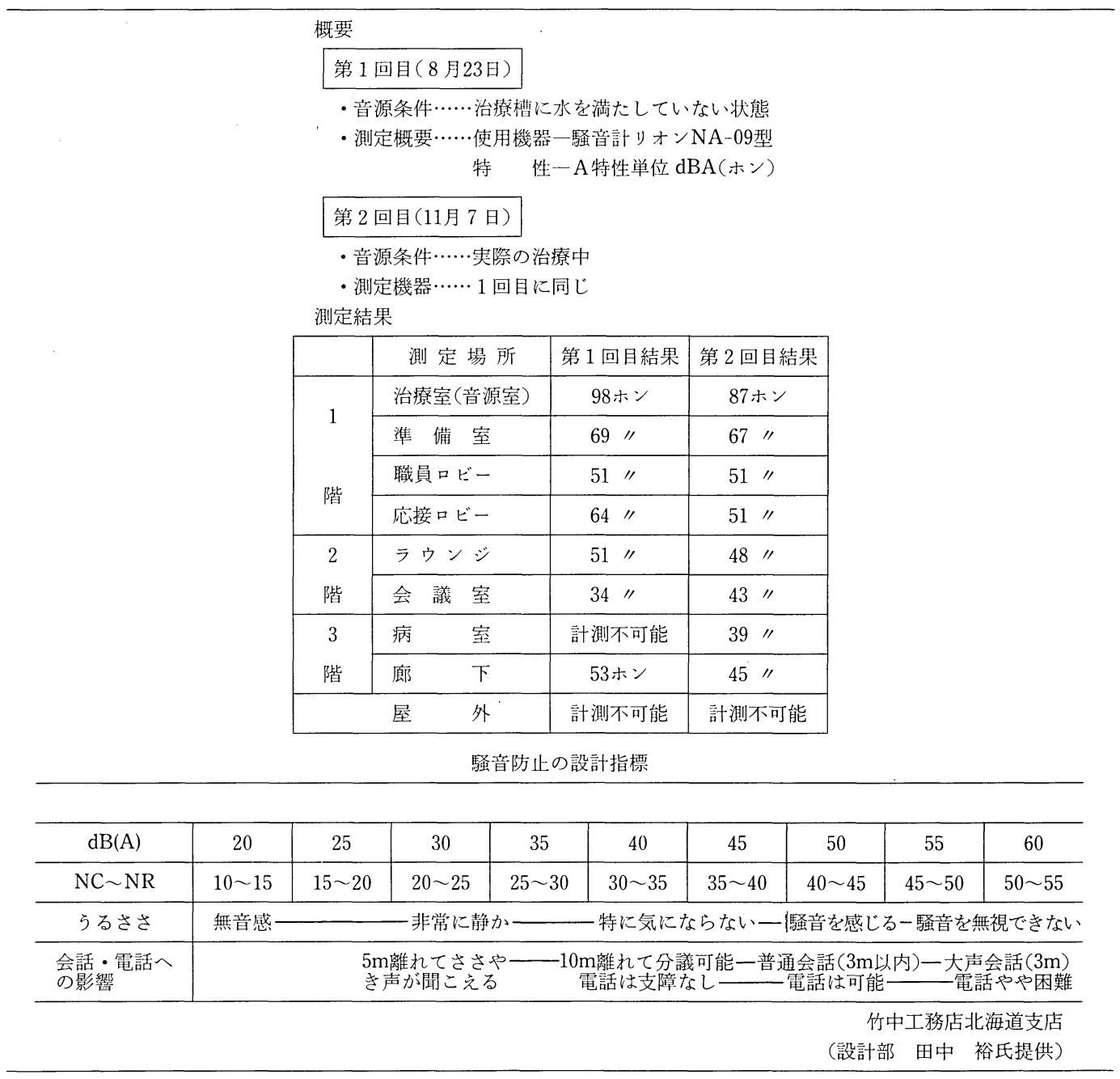

表 2 Anesthesia

\begin{tabular}{l|r}
\hline General & 8cases $(7.5 \%)$ \\
Epidural & 96 cases $(89.7 \%)$ \\
NLA & 3cases $(2.8 \%)$ \\
\hline total & $107 / 101$ cases $(100.0 \%)$ \\
\hline
\end{tabular}

表 3 Age and sex distribution

\begin{tabular}{l|r|r|r|r|r|r|c}
\hline & -19 & $20-29$ & $30-39$ & $40-49$ & $50-59$ & $60-69$ & $70-$ \\
\hline male & 0 & 11 & 14 & 17 & 15 & 11 & 3 \\
\hline femal & 0 & 4 & 7 & 3 & 9 & 6 & 1 \\
\hline $\begin{array}{l}\text { male } \\
\text { female }\end{array}$ & 30 \\
total & 101
\end{tabular}

表 4 Location and number of stones

\begin{tabular}{l|c|c|c}
\hline & Single & Multiple & Total \\
\hline Calyx & 11 & 4 & 15 \\
Calyx +Pelvis & - & 18 & 18 \\
Pelvis & 32 & 3 & 35 \\
\hline Calyx + Ureter & - & 6 & $\cdot 6$ \\
Ureter & 24 & 3 & 27 \\
\hline \multicolumn{1}{c|}{ Total } & 67 & 34 & 101 \\
\hline
\end{tabular}

ら治療することや，腎孟へ押し上げることにより成功 した.

また，X線陰性結石の 4 例を経験した. IVP (DIP), 逆行性腎血・尿管造影を併用しながら治療を試みた（表 
表 5 Size of largest stone

\begin{tabular}{rr}
\hline $1 \mathrm{~cm}>$ & 35 \\
$1-2 \mathrm{~cm}$ & 43 \\
$2-3 \mathrm{~cm}$ & 14 \\
$3 \mathrm{~cm}<$ & 9 \\
\hline total & 101 \\
\hline
\end{tabular}

表 6 X-ray density

\begin{tabular}{lr}
\hline good & 85 \\
poor & 12 \\
negative & 4 \\
\hline total & 101 \\
\hline
\end{tabular}

6 参照).

（4）Shock wave の回数と治療時間

鋳型結石や多発性結石症例群を除く，単発の結石症 例67例に対して, shock waveの回数を結石の大きさ 之位置に応じて検討したのが, 表 7 である.最小 400 回, 最大 2,200 回で, 平均 1,258 回であった。

治療時間を表 8 に示した. 30 分以内が67例(66.3\%) であった，最小時間は 7 分で，最大 60 分内であった。 後者の場合は, 両側腎結石で, 位置交換等で時間を費 した為である，通常は，11４0分間（87例：86\%）で あった。

（5）X線被曝時間

通常 5 〜0秒間であった。術者の熟練により，かな り減少した。

（6）治療後の症状（副作用）と処置

表 9 に示した.全く副作用がないものが101例中77例 （76.2\%）であった。痛みを訴えたのは17例であった。 疝痛は 1 例に経験した。これらに対しては, 対症療法 で充分であった．次いで，発熱であるが，101例中15例 (14.8\%)に認めた. 万ち 8 例は $37 \sim 38^{\circ} \mathrm{C}$ 未満で, $2 \sim 3$ 日間の一過性のものであった。 $38^{\circ} \mathrm{C}$ 以上の発熱を示し たのは 7 例認め，これを表10にをとめた。やはり，1 〜2 日間の発熱であったが，尿培養では，4例は陰性 であった。しかしながら，ESWL後, 破砕された結石 群による通過障害, 停留による腎孟炎として処置・加 療を施行した。

治療前尿培養陰性の症例で, ESWL 後, 発熱を来し た尿培養で陽性になったのは101例中12例（12\%）であ り，その同定を表11に示した。従来より結石の核より 培養で多く同定されているProteus は 1 例のみで あった。いずれも発熱した症例に対しては，抗生剂を
表 7 Number of shock wave and the size of stone

\begin{tabular}{c|c|c|c|c|c|c}
\hline \multirow{4}{*}{} & \multirow{2}{*}{$\begin{array}{c}\text { Size } \\
(\mathrm{cm})\end{array}$} & \multicolumn{5}{|c}{ Number of shock wave } \\
\cline { 3 - 7 } Calyx & $\sim 500$ & $\sim 1000$ & $\sim 1500$ & $\sim 2000$ & $2001 \sim$ \\
\hline \multirow{4}{*}{ Pelvis } & $\sim 1$ & - & 5 & 2 & - & - \\
& $\sim 2$ & - & 2 & 4 & 1 & - \\
& $\sim 3.1 \sim$ & - & - & - & 1 & - \\
& $\sim 1$ & - & - & - & - & 2 \\
\hline \multirow{2}{*}{ Ureter } & $\sim 3$ & - & - & 5 & 1 & 4 \\
& $\sim 3.1$ & - & - & - & - & - \\
\hline \multicolumn{2}{c}{ Total } & - & 7 & 8 & - & - \\
\hline
\end{tabular}

表 8 ESWL op time

\begin{tabular}{c|c|c|c|c|c|c|c|c}
\hline mts. & -10 & -20 & -30 & -40 & -50 & -60 & $61-$ & total \\
\hline No. of Pts & 3 & 17 & 47 & 23 & 15 & 2 & 0 & 101 \\
\hline
\end{tabular}

表 9 Postoperative complications

\begin{tabular}{|c|c|c|}
\hline \multirow[t]{4}{*}{ ( I ) } & Macrohematuria(all cases) & (duration) \\
\hline & 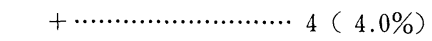 & 1 day \\
\hline & 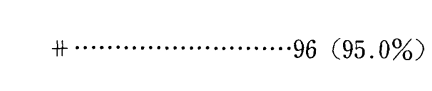 & $\left\{\begin{array}{l}1 \text { day } \\
2 \text { days } \\
3 \text { days }\end{array}\right.$ \\
\hline & \#(with blood clots) $\cdots 1$ ( $1.0 \%)$ & 1 day \\
\hline \multicolumn{3}{|c|}{ (II) Other symptoms } \\
\hline \multicolumn{3}{|c|}{ Pain + Fever $\cdots \cdots \cdots \cdots \cdots \cdots(7.9 \%)$} \\
\hline \multicolumn{3}{|c|}{ Pain ……............. 9 ( $8.9 \%)$} \\
\hline \multicolumn{3}{|c|}{ Fever $\cdots \cdots \cdots \cdots \cdots \cdots \cdots \cdots \cdots \cdots \cdots \cdots \cdots$} \\
\hline \multicolumn{3}{|c|}{ 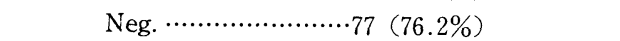 } \\
\hline
\end{tabular}

表10 7 cases of fever(over $38^{\circ}$ C)after ESWL

\begin{tabular}{|c|c|c|c|c|}
\hline $\begin{array}{l}\text { No. of } \\
\text { cases }\end{array}$ & $\begin{array}{c}\text { duration } \\
\text { (days) }\end{array}$ & $\begin{array}{c}\text { stone size } \\
(\mathrm{mm})\end{array}$ & position & urinary isolates \\
\hline 1 & 2 & \multicolumn{2}{|c|}{ complete staghorn } & neg. \\
\hline 2 & 7 & $30 \times 25$ & pelvis & Ps. putida \\
\hline 3 & 2 & $30 \times 25$ & pelvis & Ps. aeruginusa \\
\hline 4 & 2 & $20 \times 15$ & pelvis & $\begin{array}{l}\text { Ps. aeruginosa } \\
\text { E. coli }\end{array}$ \\
\hline 5 & 1 & $\left\{\begin{array}{r}17 \times 15 \\
9 \times 9\end{array}\right.$ & pelvis & neg. \\
\hline 6 & 1 & $16 \times 13$ & $\left\{\begin{array}{l}\text { ureter } \\
\text { pelvis }\end{array}\right.$ & neg. \\
\hline 7 & 2 & $10 \times 5$ & calyx & neg. \\
\hline
\end{tabular}

投与した. 血液培養で 1 例 E. coli が検出された。

図 7 に示した如く 5 例に, shock waveを照射した 
表11 Urinary isolated bacteria after ESWL

\begin{tabular}{l|c}
\hline & $\begin{array}{c}\text { No. of } \\
\text { cases }\end{array}$ \\
\hline E. coli & 5 \\
Ps. aeruginosa & 3 \\
S. marcescence & 2 \\
Proteus spp. & 1 \\
Ps. putida & 1 \\
\hline Total & 12 \\
Negative & 89 \\
\hline
\end{tabular}

図 7

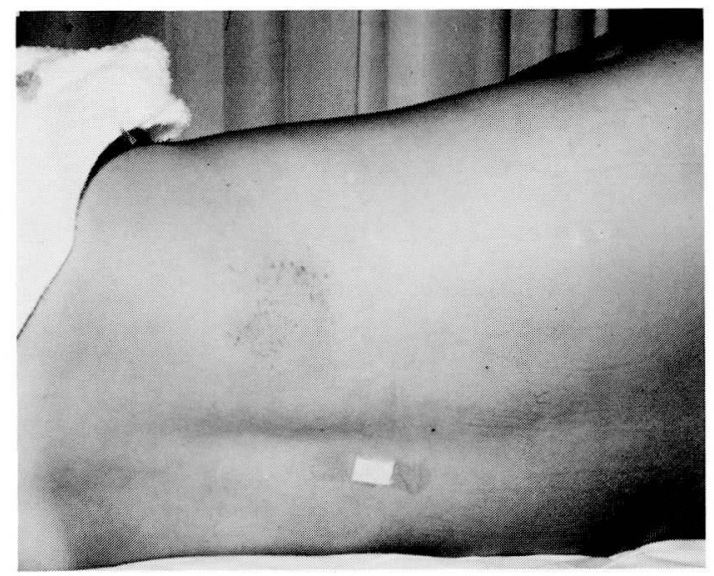

皮膚の部位々，通過した反対側の皮虞の部位に，一部 点状皮下出血を伴ら発赤, 腫脹を認めた。 これは無処 置で治瘉したが, 原因については不詳である. 皮膚に 附着した微量の空気によると考学られているが，検討 中である.

次いで, 破砕された結石が, 尿管に停留し腎孟炎を 併発した 5 症例に対して, 尿管口切開を, 無麻酔下に 加えて, 砂状の結石を排泄させた。 この事により, 全 例が，翌日より解熱した。

その他, ESWL 施行中より, 全例に肉眼的血尿を認 めた，その血尿は，1２日間持続したが, 特に処置 はしなかった（表 9 参照）.

（7）治療後の血液生化学的所見

血中 CPK が一時的に上昇する症例を認めたが，原
因については不詳である。その他の血液生化学的所見 は, 特に異常を認めなかった。しかし, 短期間の follow upであり, 今後, 長期間にわたって追求する必要があ ろうと考觉ている.

(8) 結石排泄期間

（i）治療後の結石の尿路中への移動・排泄動向

Follow up 可能であった. 腎結石の54症例に対して， 破砕された結石の流出状況を検討した。破砕された結 石は，ESWL 施行した翌日より，54例中34例（63\%) に少しずつ，体外へ自然排泄を認めた。

また，尿管結石の37例では，16例（50\%）に，翌日 より少しずつ排泄を認めた。

(ii) 完全排泄された症例

ESWL 後 7 日目で, 結石が完全排泄したのは101例 中 8 例 $(8 \%)$ であった.

更に 2 カ月間の follow upでは, 101例中47例 (46.5\%) であった。 らち，腎結石症は，29例（62\%） で, 残りの18例 (38\%) は尿管結石症であった（表12, 表13参照).

\section{（9）排泄された結石の大きさ}

4 症例に於いて, ESWL 治療後 24 時間以内に排泄さ れた結石の大きさ（長軸）を測定した結果を表14に示 した. 99\%が， $2 \mathrm{~mm}$ 以下であった。次いで，20例に於 いて, 治療後 2 週間以内に排泄した全ての結石の大き さ (長軸) を測定した (表15参照) が，やはり $2 \mathrm{~mm}$ 以 下が97\%であった。しかし， $5 \mathrm{~mm}$ 以下（最大 $7 \mathrm{~mm}$ )の 比較的大きな結石が，2,623個中 10 個 $(0.4 \%)$ 認めた ことは注目される。

（10）排泄された結石の成分

分析し得た 90 例を検討し，表16に示した。苳酸カル シウムを中心とした結石成分が90例中74例（82\%）で あった。稀有な cystine 1 例と尿酸 2 例を経験した。

表12 Post. ESWL x-ray control follow up period 3-60days

\begin{tabular}{c|c}
\hline Stone free & $47 \operatorname{cases}(46.5 \%)$ \\
\hline Residual sanciy stone & $54 \operatorname{cases}(53.5 \%)$ \\
\hline
\end{tabular}

表13 Post ESWL x-ray control follow up period; 1-8 weeks

\begin{tabular}{c|c|c|c|c|c|c}
\hline & 1 week & 2 weeks & 3 weeks & 4 weeks & 8 weeks & total \\
\hline $\begin{array}{c}\text { No. of stone free } \\
\text { (total No.) }\end{array}$ & 8 & 11 & 9 & 6 & 13 & $47(46.5 \%)$ \\
$(8)$ & $(19)$ & $(28)$ & $(34)$ & $(47)$ & \\
\hline
\end{tabular}


表14 The size of stone fragments discharged within 24 hours after ESWL (4 cases)

\begin{tabular}{|c|c|c|c|c|c|c|}
\hline 症例 & $\sim 1 \mathrm{~mm}$ & $\sim 2 \mathrm{~mm}$ & $\sim 3 \mathrm{~mm}$ & $\sim 4 \mathrm{~mm}$ & $\sim 5 \mathrm{~mm}$ & $5 \mathrm{~mm}$ 以上 \\
\hline $\mathrm{G}$ & 58 & 13 & - & - & - & - \\
\hline I & 105 & 29 & 3 & - & - & - \\
\hline $\mathrm{J}$ & 47 & 6 & - & - & - & - \\
\hline \multirow[t]{2}{*}{$\mathrm{K}$} & 15 & 15 & - & - & - &. \\
\hline & $\begin{array}{c}225 \\
(77 \%)\end{array}$ & $\begin{array}{c}63 \\
(22 \%)\end{array}$ & $\begin{array}{c}3 \\
(1 \%)\end{array}$ & & & \\
\hline
\end{tabular}

表15 The size of stone fragments discharged within 2 weeks after ESWL (20 cases)

\begin{tabular}{l|r|r}
\hline size & number & \multicolumn{1}{c}{$\%$} \\
\hline$-1 \mathrm{~mm}$ & 2157 & 82.2 \\
-2 & 382 & 14.6 \\
-3 & 51 & 1.9 \\
$4-7$ & 33 & 1.3 \\
\hline & 2623 & 100.0 \\
\hline
\end{tabular}

（11）入院期間

入院期間は, 鋳型結石等大きな結石症例や, 副作用 の併発を起こさなかった症例は, 通常, 数日間であっ た.

（12）治療後の腎機能

Follow up 期間が短いので明白でないが，血液生化 学的所見と同様 IVP (DIP) 上での評価では著変な かった. 勿論, 結石による stasis, 水腎症の寛解は, 従 来の手術的剔出後の腎機能回復程度と同様であった。

（13）泌尿器系以外の合併症

心疾患, 循環器系疾患, 消化器系疾患等への影響は なかったし，併発した症例もなかった。

\section{症例供覧}

主なる症例を供覧する。

症例 $1 ： 60$ 歳女性, 左腎鋳型結石である. 図 8-1は 術前の単純撮影像(以下 KUB と記す)である. 図 8-2 は, 上腎杯・腎孟に位置する結石に対して ESWL 施行 (shock wave 2,100回, 治療時間45分）し，2 日目の KUB である. 上腎杯, 腎孟にまたがる結石の一部が破 砕され，更に尿管に流出されている。図 8-3 は20日目 の KUBで, shock waveをあてた結石は全で排泄さ れ，未治療の下腎杯に結石陰影がある。そこで第 2 日 目 ESWL 施行（shock wave 2,100回，40分間）した。 図 8-4 は2 回目 ESWL 後 5 日目の KUB である。一 部砂状の結石を残すのみである，全経過を通じて，第
表16 Chemical analysis of excreted stones

\begin{tabular}{|c|c|}
\hline & No. of $\operatorname{cases}(\%)$ \\
\hline Ca oxalate & $18(20.0)$ \\
\hline +Ca phosphate & $47(52.2)$ \\
\hline$+\left\{\begin{array}{l}\text { Ca phosphate } \\
\text { Ca carbonate }\end{array}\right.$ & $4(4.5)$ \\
\hline +Uric acid & $4(4.5)$ \\
\hline$+\left\{\begin{array}{l}\text { Ca phosphate } \\
\text { Ammonium hydrogen urate }\end{array}\right.$ & $1(1.1)$ \\
\hline Ca phosphate & 0 \\
\hline + Ca carbonate & $7(7.8)$ \\
\hline Uric acid & $2(2.2)$ \\
\hline Sodium hydrogen urate & $3(2.2)$ \\
\hline Magnesium ammonium phosphate & $3(2.2)$ \\
\hline Cystine & $1(1.1)$ \\
\hline Total & 90 \\
\hline Not examined & 11 \\
\hline
\end{tabular}

1 日目 ESWL 後 4 日間 $\left(38^{\circ} \mathrm{C}\right.$ ) 発熱（腎孟炎）をみた のみで，特に副作用もなく，無処置で，1 1 月間弱で 成功した. 尚, 結石分析の結果は, 燐酸カルシウ $468 \%$, 炭酸カルシウム $30 \%$, 蓚酸カルシウムが微量であった。 症例 2：22歳女性, 左腎孟結石である. 図 9-1は KUB で，左腎盂に $17 \times 15 \mathrm{~mm}, 15 \times 12 \mathrm{~mm}$ の 2 個の淡 い結石陰影像を示す。図 9-2 は術前の IVP 20分)で, 各腎杯の拡張を示す. ESWL 施行 (shock wave 1,400 回，30分間)した 24 日目の KUB (図 9-3) と IVP (図 9-4)である. 完全排泄され, IVP 上腎機能が回復し, 形態も正常化している. 結石分析の結果は, 尿酸水素 アンモニウム $98 \%$ であった。

症例 $3: 36$ 歳女性, 右腎孟結石である. 図10- 1 は術 前の KUB で $20 \times 14 \mathrm{~mm}$ 結石陰影像を示す. ESWL 施 行 (shock wave 1,300回，35分間）直後，破砕された 結石が中・下腎杯, 腎盂に拡った所を図10-2 に示した。 図10-3 は ESWL 後 2 日目の KUB である. 図10-4は 7 日目の KUBに，ごくわずか下腎杯に砂状結石が残 
図 8 症例 1 68歳 (女) 1. 術前単純像 (KUB と記す)，2. ESWL 後 2 日目，3. 2 回目 ESWL 施行直前の KUB ( 1 回目より20日目), 4. 2 回目 ESWL 後 5 日目 (1 回目25日目）のKUBで, ごく 1 部残石を認める程度に排泄された.
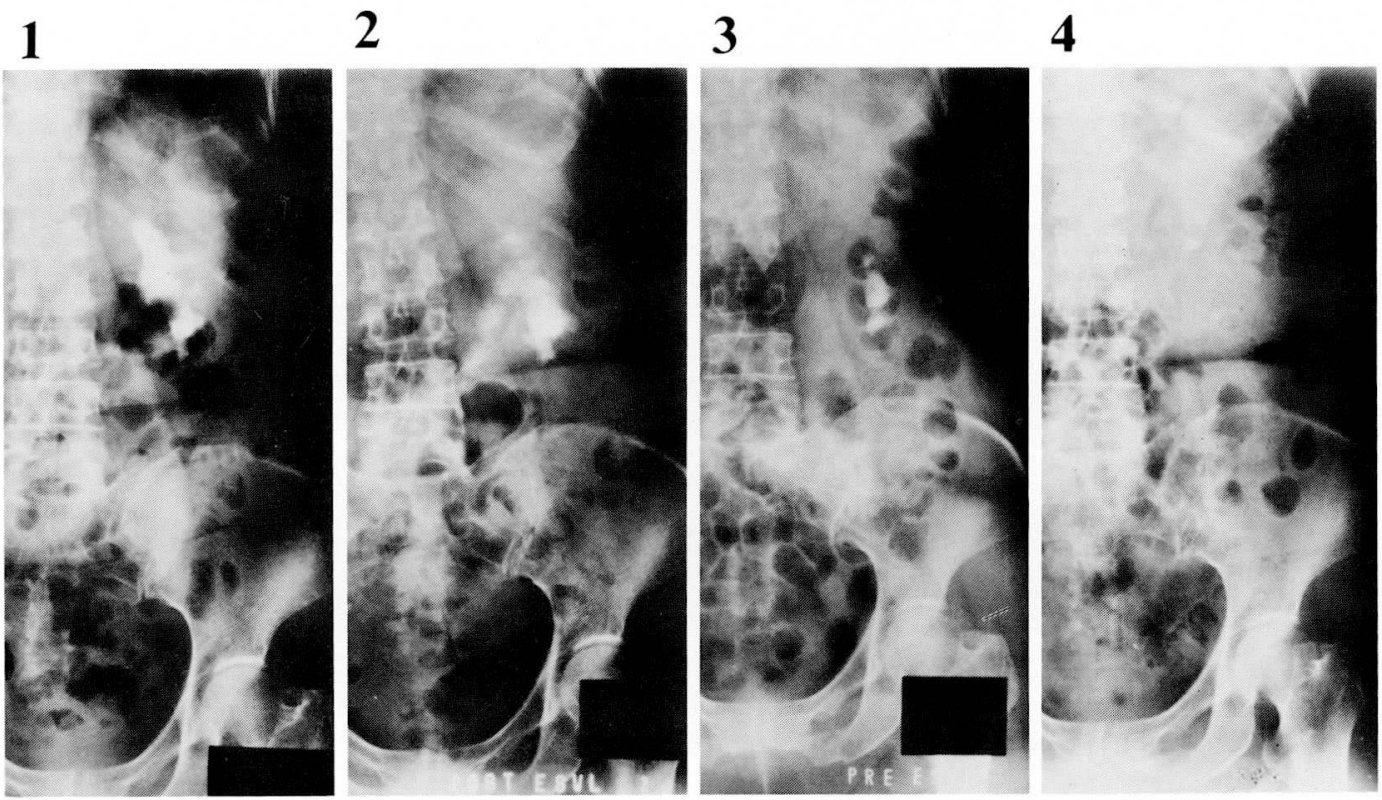

図 9 症例 2 22歳（女）1．2. 術前の KUB, IVP（16分）像，3.4. ESWL 後24日 目の KUB, IVP（15分）像である。完全排泄された.
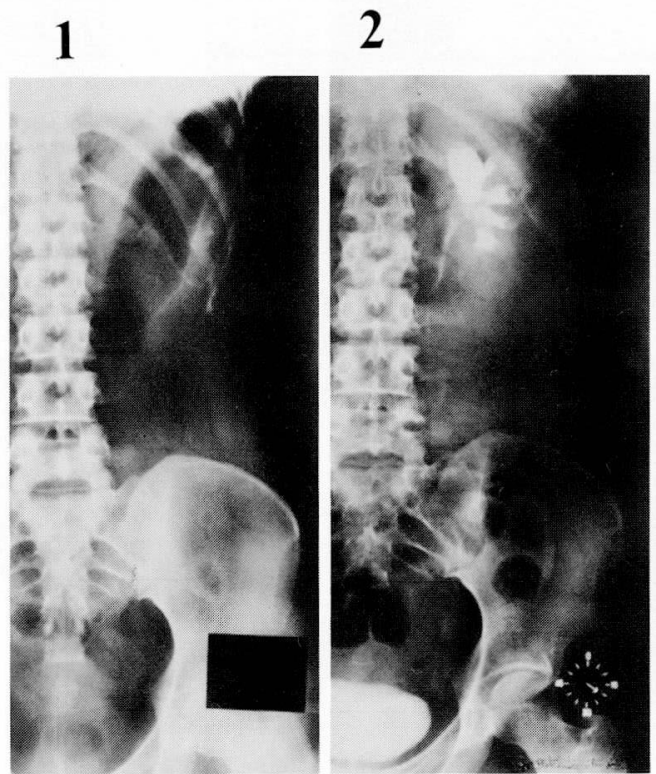

3

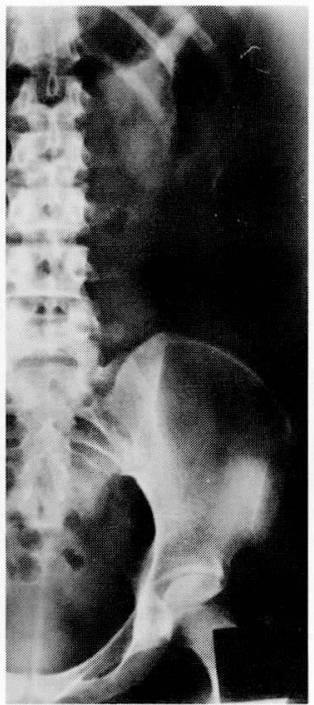

4

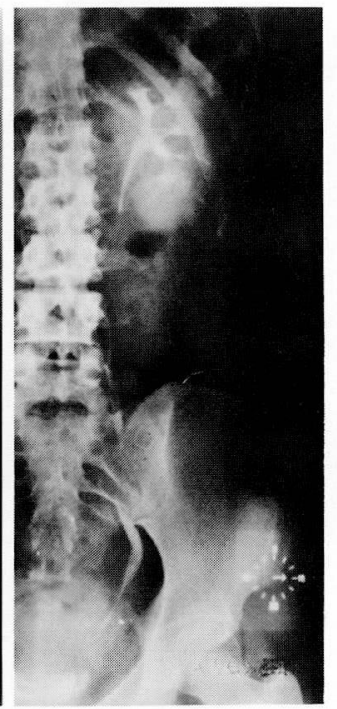

存している.図10-5，6 は14日目の KUB と IVP 像で ある，完全結石排泄を認めた，結石分析の結果は，苳 酸カルシウ $498 \%$ ，燐酸カルシウムが微量であった。
症例 $4 ：$ 50歳男性，左尿管結石である. 図11-1，2 は術前の KUB $(6 \times 10 \mathrm{~mm}$ の結石陰影像を認める) と IVP 像である.ESWL (shock wave 800回，20分間) 
図10 症例 3 。36歳 (女)，1。ESWL 直前の KUB, 2. ESWL 直後の KUB で, 各腎 杯に破砝された結石が拡っている。3。ESWL後2 日目の KUB，4ＥSWL後７日 目，一部砂状結石が残存．5.6. 完全排石を認めた ESWL 後14日目の KUB と IVP 像である。

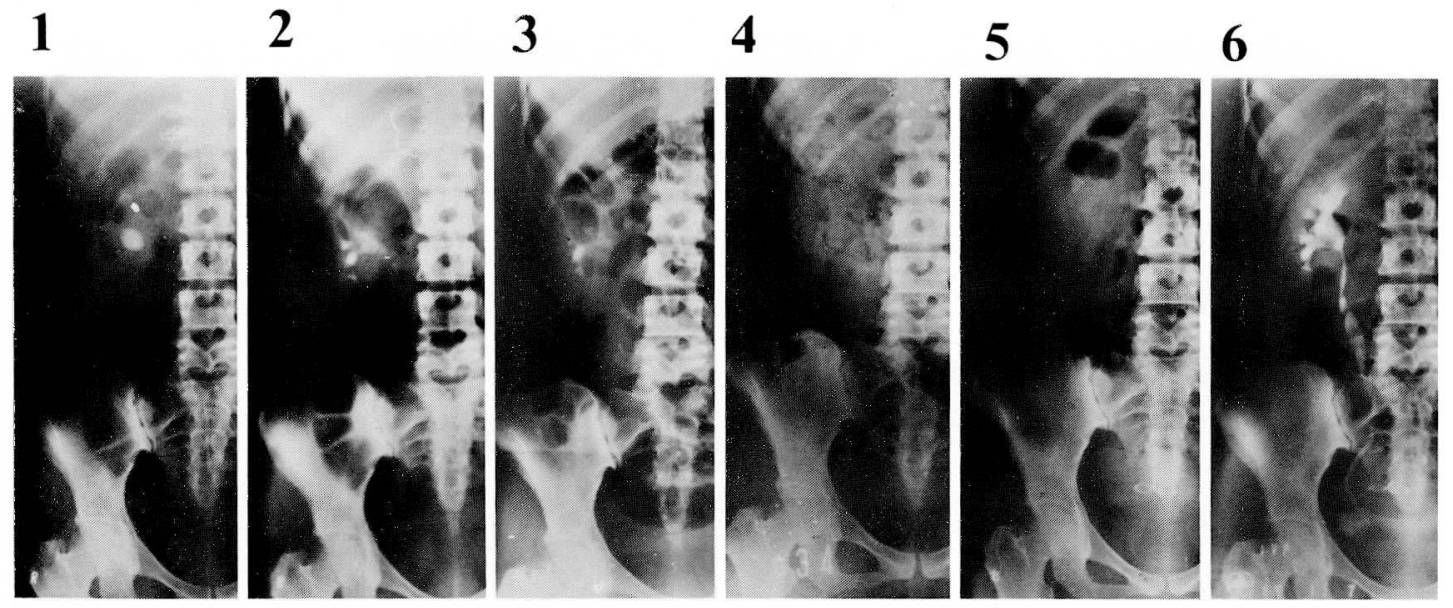

図11 症例 4。58歳(男)，1．2．ESWL 直前の KUB と IVP 像である. 3.4. ESWL 後14日目の KUB とIVP（10分）像である。完全排泄された。

1

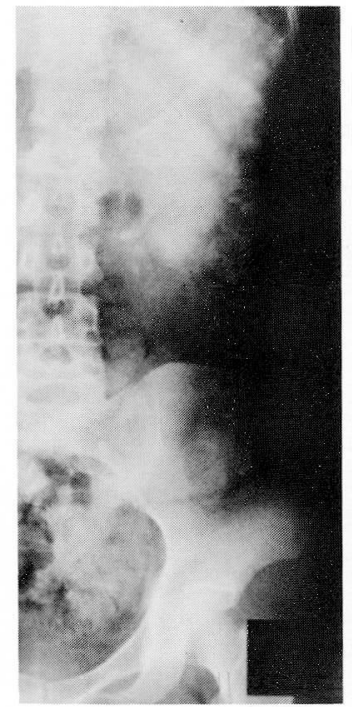

2

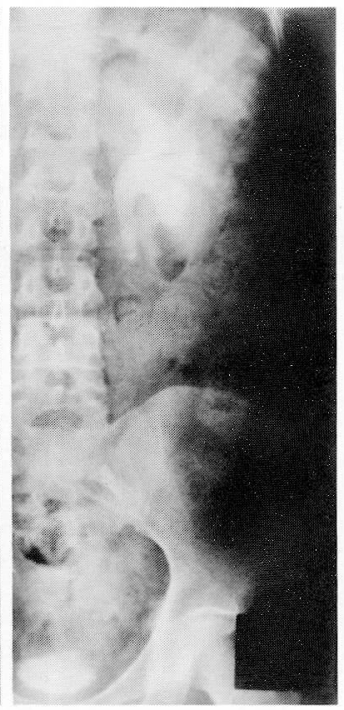

3

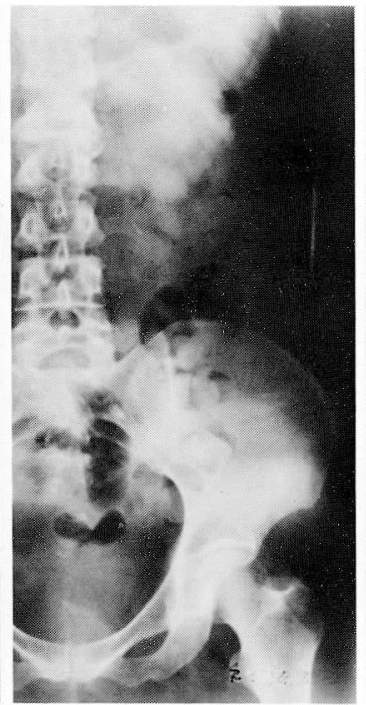

4

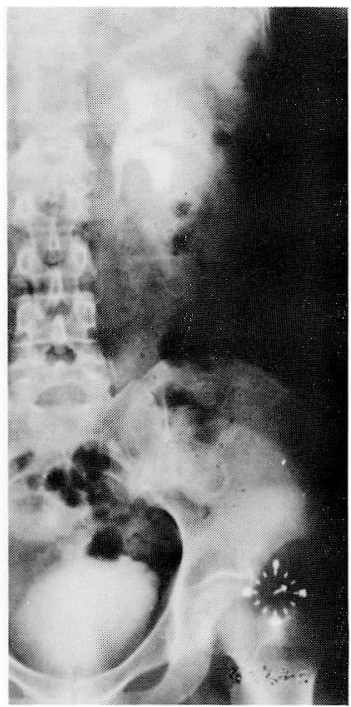

施行し，14日目の KUB(図11- 3) と IVP 像(図11-4) で，結石は完全排泄され，術前の水腎症も回復した。 結石分析は未提出である。

症例 5 ：39歳男性，単腎症で右尿管結石 $(6 \times 6 \mathrm{~mm})$ である. 結石陰影像が淡い結石の為, 図12-1の如く逆 行性に尿管バルーンカテーテル插入し, 約 $5 \mathrm{~cm}$ 腎の方
へ押し上げ（図12-2），直ちに ESWL（shock wave 1,400回，28分間)施行したものである。術後 1 週間で 完全排石された。図12-3，4 はESWL後25日目の KUB と DIP 像である。結石分析の結果は, 蓚酸カルシ ウム $98 \%$ ，燐酸カルシウム微量であった. 
図12 症例 5. 39歳 (男), 1.2. 結石陰影の為, 逆行性尿管バルーンカテーテル插入

し, 結石を上方へ押し上げた時の像である．3.4. ESWL 後25日目の KUB と DIP （20分）像である。完治した。

1

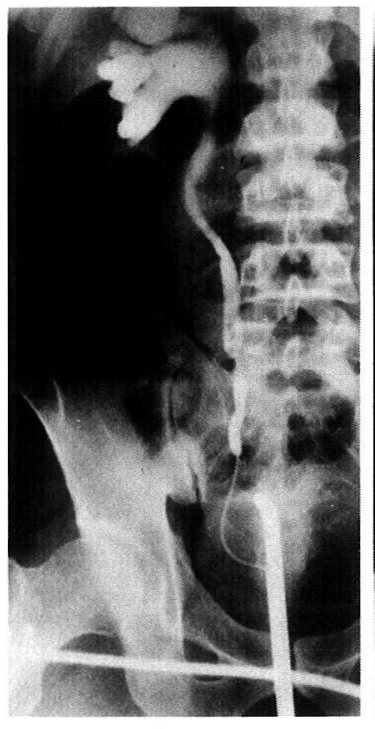

2

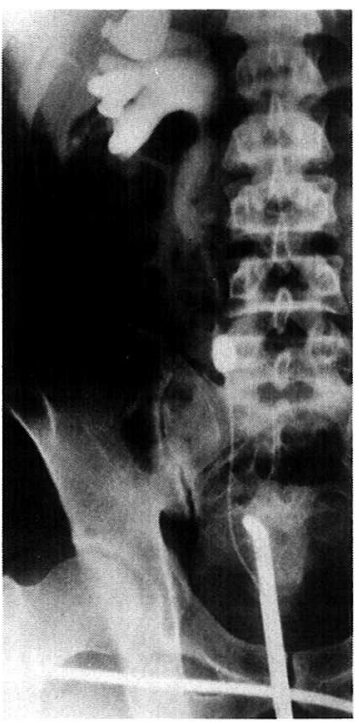

3

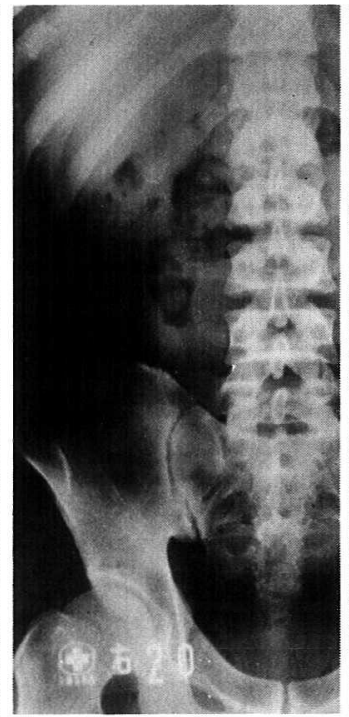

4

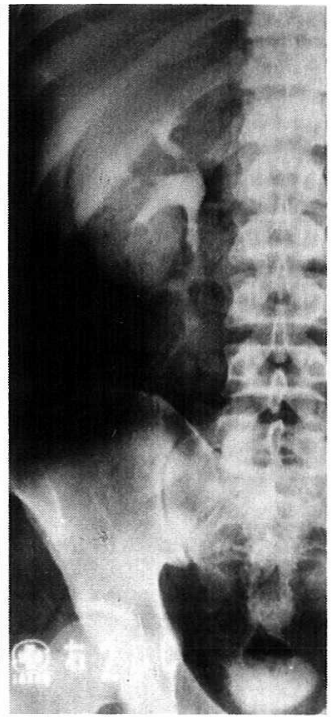

考按

ESWL の治療の適用は, 当初かなり慎重に施行した と報告されているが3)4)，自然排泄を予想されるごく小 さな結石は，勿論適用外であるが，ここ1〜2年より 絶対的適用外は，かなり限定されて来たので，かなり 広い範囲の上部尿路結石症に行われて来ている。

最近の ESWL 適用外について要約すれば，(1)内科 的疾患として, 未治療の出血性素質のある症例, 強度 の肥満, 頻回の不整脈のある症例のみである。(2)器械 (懸架システム)そのものから，体重 $120 \mathrm{~kg}$ 以上，身長 $140 \mathrm{~cm}$ 末満の症例である。(3)泌尿器系疾患として尿管 閉塞, 腎実質性結石, 腎杯唕室結石等である。(4)その 他, KUB で, 陰影像の淡い結石の場合も適用外である が, 従来の泌尿器科的処置を併用する事で, 成功する こともある。我々も症例供覧 5 例目（図12-1，2，3， 4 参照) の如く，尿管がルーンカテーテル使用により 可能であった。腸骨稜以下の尿管結石も適用外である が，尿管鏡的操作等により，結石を腎の方へ押し上げ ることで可能であり, 我々も 2 例成功してあり絶対的 適用外ではなくなった。なた強度の尿管閉塞, 尿路感 染症の存在する場合でも, PCN (腎瘦術), 抗生剂の投 与，尿管鏡的操作により適用となる症例があると考光 る。我々も PCN を予定していた尿管狭窄の存在する
症例に対して, ESWL 施行した所 ( 2 例) 何んら処置 せず完全結石排泄に成功しておう，必ずしも尿路閉塞 が適用外とはならない。程度差によるだろうと考学る。

次いで, ESWL の絶対的適用, 比較的適用について であるが，腎の先天性疾患，単腎症，既往に何らかの 腎の手術をうけている症例。腎機能不全, 両側腎・尿 管結石症等が上られる。我々は，馬蹄鉄腎に腎孟結石 を伴う症例を経験したが, ESWL，後 2 週間で結石を完 全排泄に成功している。また，既往に手術をうけた症 例（3 例）に対して，ESWL 施行した。弓ち 2 例に尿 管狭窄を認めていたが，いずれも何んら処置せず成功 した. Chaussy らの報告でも ${ }^{4)}$, 既往に 1 回以上の結石 の剔出術をうけたことのある症例が ESWL 施行症例 の $40 \%$ もったとし，乙かも特に問題なかったとして いる。これらの事から, 外科的手術方法で, 問題があ り, 術後副作用が併発される事が予想される結石症に 対しても当然, ESWLの適用とならう.

麻酔に関して, 欧米では, 全身麻酔下で施行されて いる例が，10\%以上と報告されている4). 我々は, 硬膜 外麻酔で, しかも 1 回注入法で充分であると考兄てい る. ESWL 治療後の疼痛, 排泄を容易にする利点は あって子硬膜外麻酔で turbing する事は, 温水槽につ ける事もあり, 感染の心配もあり, 出来るだけ容易な 
麻酔，軽い麻醉をかけ，ESWL 治療後の体動，運動を 早めにさせるのが良いと考旮ている．1984年 Chaussy らの報告5)では，75\%が硬膜外麻酔で治療していると いう。我々は， $90 \%$ 同法で施行し，何んら問題なかっ

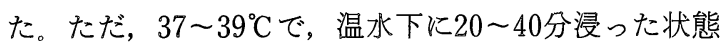
は，皮膚呼吸抑制等が加わり，心血管系，肺呼吸器系 への影響も想定され，向後検討する予定である。

年齢に関して，我々は，20歳から74歳の男女 101 例に 107回治療したが，西独でも ${ }^{6)} ， 6 ７ 9$ 歳とあらゆる年 齢層に施行し，更に高年齢に適用を拡げている，治療 時間が短かいこともあり，軽い麻酔さえかけれれば高 年齢でも充分適用になろう。

結石の位置について，腎及び腎附近の尿管結石症が 適応である，最近は中。下部尿管結石に対しても尿管 鏡的処置により，押し上げてから ESWL 施行するか， 尿管カテーテルを插入して水を注入しつつ施行するこ とで治療が可能になった。

結石の大ささ, 個数に関して, 大した問題はないが, それに対する shock wave の回数が問題となる。我々 は, 主に700〜2,200回であり，1,500回以下が79\%で あったが, Munich 大学一派では5), 978土134回であっ たと報告している。これは，腎結石の場合には，我々 の治療経験から明らかのよらに，大きさに比例して回 数が多い事から，単なる技術的評価判定の差は推定出 来ない。

治療時間に関して, Chaussy ら5) $54 \pm 25$ 分間で あったと報告している. 我々も $86 \%$ が，11〜40分間で あった。また，X線被曝時間であるが，我々は $5 \sim 60$ 秒間であったが，西独では5)，125士53秒間と報告して いる.

shock wave 50 100回毎にX線にて結石破砕状況 を確認するので，もしX線に陰影が淡い場合は，X線 透視を必要とするので, 被曝時間は長くなる。しかし， 熟練により，減少されることは確実である。

術後副作用と処置について, 副作用は殆んどなかっ たが，欧米でも然りであるが，しかし，1984年の報告 では5)，945例中1,068回の ESWL 施行して, PCNを43 例に，尿管への処置を33例に施行したと報告している。 従って，10１5\%の割合で, ESWL後, PCN, 尿管鏡 的処置, 手術等を併用する必要があろう。我々も，101 例中 107 回施行して，5例に尿管口切開を加光ており， 当然予想される併発に対する処置を，いつすべきか, このまを観察すべきかが問題になる。しかし，大きな 結石 (直軸 $2 \mathrm{~cm}$ 以上) 症例に対しては, 破砕される結
石が多い為, 当然, 流出の停滞により, 腎典炎が併発 されるので, 早めに内視鏡的処置が必要である。

その他の副作用として上られるのは，術後の結石の 排泄されるときの痛みであるが，それに対して71\%に 鎮㾏剤を投与したと報告されている5゙。また，28\%に疝 痛があったとしているが，我々の経験では 1 例のみが 疝痛があったが, その他の症例は, 鈍痛で17例(16.8\%) に経験した。

ESWL 後の結石排泄動向に関して，1984年の報告で は5), $90 \%$ が 3 カ月間の経過観察で, 完全に結石が消失 したと報告している。我々の場合, 短期間の経過観察 であるが，47例（46.5\%）に結石の完全消失をみた。 そこで, ESWL 後 3 カ月の経過観察期間をみて, 治療 の完了，再治療すべさか, 決めるべきであろう。勿論, KUBで, 明らかに結石の破片として残存している場 合は，再治療すべきであろう，西独での報告で7), 1983 年 10 月末日で, 964 例施行し, 2 年間の経過観察期間で, $9.3 \%$ 残存結石があったが, 外科的剔出術を要したの は0.4\%のみであったとしている。1984年 2 月の

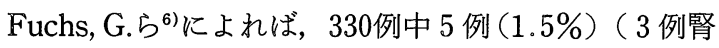
孟, 2 例尿管結石）に手術的剔出を行ったと報告して いる。更に, チスチン結石の 2 例は粉々に破砝されず, 大きな破片状の結石にしか破砕されない為, PCN を併 用して剔出したと報告している。

いずれにせよ，ESWLにより，結石が破砕されるこ とは, 充分判明した。しかし, その破砕された結石群 をどう排出させるかが問題となる。自然排泄も可能で あるが，入院期間，排泄に長期間を要すると予想され る大きな結石，鋳型結石は，PCN を併用する事は充分 考慮されるべきである。また，それを併用することに より，成功率を一層たかめるだろらと考える。

腎機能について, 我々はIVP 像の久の判定の data しかないが，西独の報告では 2 年間以上の経過観察期 間で当然回復しており，増悪した例はいなかったと報 告している5)6

泌尿器系以外の合併症に関しては，多くの報告はな い. 我々も特に経過観察中ではあるが, 認めていない。 ESWL 後の死亡報告として, 西独に於いて ${ }^{5}, 945$ 例中, 治療前, 心筋梗塞があった例で, 治療後 1 例死亡した と報告がある，その他，超音波検査にて，6例に局所 の腎被膜内血腫を認めたと報告している。

\section{結語}

1。上部尿路結石症101例（男子71例, 女子30例）に 対して ESWL 施行した。5〜60日間の経過観察にて, 
らち47例に結石の完全消失排泄に成功した。 しかし残 りの症例もごくわずかの残石あるのみで, 自然排泄が, 期待出来る結石の大ささであった。

2. 適用外として, ESWLの器械の物理的要素から, 身長 $140 \mathrm{~cm}$ 末満, 体重 $120 \mathrm{~kg}$ 以上の症例である. shock wave の要素から内科的疾患として, 出血性素因があ り未治療症例, 強度の肥満, 強い不整脈のある症例等 である.

3. 泌尿器系適用外として, 自然排石が予想される小 結石症例, 完全尿路閉塞例, ESWL の器械的要素から, 膀胱結石, 及び下部尿管結石 (腸骨陵以下) 例である.

4. 適用は上記 2,3 以外の腎・尿管結石症であった。

5. 治療は, 硬膜外麻酔で充分であった。治療時間は 20〜40分間であった. shock wave の日数は 1,500 回以 下が約 $80 \%$ であった。

6. 治療後, 肉眼的血尿を $1 \sim 2$ 日間の持続であるが 全例に認めた。

7. 副作用は, 特に認めなかった. あったとしても鈍 痛, 発熱 (腎盂炎) で17\%に認めた。

8. 入院期間は数日間で充分であった. 簡便, 完全か つ迅速性であった事が証明された。

9. 術後経過観察期間は 3 力月必要である. その間長 軸 $2 \mathrm{~mm}$ 以下の小結石は無処置で, それ以上の残存結石 の場合は 2 回目の治療が必要であった.

10. 結石は, 破砕される事が確認された。しかし, $5 \%$ PCN, 尿管鏡的内視鏡的処置の併用が必要で あった. しかし上部尿路結石症に対しては, 向後, 従 来の外科的剔出術にかわり, ESWL が中心的役割を果 たすだろらと考觉る。

最後に, ESWLの実際の技術指導をしていただいた Eisenberger, F., Fuchs, G., Miller, K. (Department of
Urological Clinic, Katharinen Hospital, Stuttgart, FRG : Director Prof. Eisenberger, F.) に深謝いたします。また， 御校閱を承った新島端夫教授, 東原英二講師 (東京大学, 泌 尿器科）に深謝いたします。

尚, 本論文の要旨は, 昭和 59 年 12 月 1 日第 274 回日本泌尿 器科学会北海道地方会にて発表した。 また, 昭和59年12月 15 日 lst Korea-Japan Urological Congress（神戸市）に発表 した.

\section{文献}

1) Chaussy, C.H.: Extracorporeal shock wave lithotripter. In : New aspects in th treatment of kidney stone disease. Karger, 1982.

2) Chaussy, Ch., Brendel, W. and Schmiedt, E.: Extracorporeally induced destruction of kidney stones by shock waves. Lancet, 11, 1265-1268, 1980.

3）阿岸鉄三, 高橋通子, 光野貫一：体外衝撃波による 腎結石破碎。医学のあゆみ，126(2)，105-108， 1983.

4) Chaussy, Ch., Schmiedt, E., Jocham, D., Brendel, W., Forssmann, B. and Walther, V.: First clinical experience with extracorporeally induced destruction of kidney stones by shock waves. J. Urol., 127, 417-420, 1982.

5) Chaussy, Ch., Schüller, J., Schmiedt, E., Brandl, H., Jocham, D. and Liedl, B.: Extracorporeal shock-wave lithotripsy (ESWL) for treatment of urolithiasis. urology, XXIII(5), 59-66, 1984.

6) Fuchs, G.: Extracorporeal shock wave lithotripsy (ESWL): Clinical experiences and results. ESWL 研究会発表より, 1984 (4).

7）ミュンヘン大学よりの personal Communication, 1983 (10).

（1984年12月 26 日受付） 